\title{
ARTYSTYCZNA PRZYJAŹŃ W ATELIER MADOURA MICHEL SIMA, PABLO PICASSO ${ }^{1}$
}

\author{
Agnieszka CHWIALKOWSKA (Katolicki Uniwersytet Jana Pawla II w Lublinie)
}

Druga połowa XIX wieku przyniosła rosnące zainteresowanie ceramiką, a jedną z przyczyn wpływających na jej popularność było zakwestionowanie podziału pomiędzy przewodnimi dziedzinami sztuki a pomniejszymi. Sprzyjało to interdyscyplinarności artystów i ich eksperymentom. Twórcy zaczęli sięgać po nowe medium, współpracując jak Rodin z manufakturą w Sèvres, Gauguin z Ernestem Chaplet czy Vlaminck w atelier André Metthey à Asnières ${ }^{2}$.

Wiek XX, a szczególnie lata powojenne to okres największej świetności Vallauris, niewielkiego miasta położonego w południowej Francji w basenie Morza Śródziemnego, słynącego z tradycji ceramicznych. Wydobywane na jego terenie złoża gliny ogniotrwałej były wykorzystywane już $\mathrm{w}$ czasach gallo-romańskich do produkcji cegieł i garnków. W wieku XV miasto zostało zdziesiątkowane przez zarazę i wojnę, jednakże szybko przystąpiono do jego odbudowy, nie zapominając o naturalnych zasobach. Pod

${ }^{1}$ Niniejszy tekst porusza jednie fragmentaryczne zagadnienia, dotyczące artystycznej działalności Michela Simy. Buduje kontekst dla analizy stylistycznej ceramiki artysty, która stanowi osobny rozdział, niemieszczący się w artykule z powodów oczywistych, w doktoracie autorki. Autorka pracuje nad rozprawą pt. Michel Sima - ze Stonimia do Paryża. Życie i twórczość zapoznanego artysty pod kierunkiem dr hab. Doroty Kudelskiej Prof. KUL.

${ }^{2}$ A. d'Agliano, Ceramika. Wiek XIX. [w:] Ceramika XV-XX wieku, red. M. Cebo-Foniok, s. 158 . 
koniec XVI wieku funkcjonowały na tym terenie trzy fabryki ceramiczne, zaś w 1829 roku pracowały już trzydzieści dwie. Rozwój kolejnictwa umożliwił ekspansje produkcji, sprawiając, że rodzinne pracownie zaczęly się łączyć w większe firmy, co w znaczny sposób ukształtowało lokalny przemysł. Początek XX wieku przyniósł spadek zainteresowania ceramiką użytkową, wpłynęło to na wykorzystanie w produkcji masowej takich materiałów jak aluminium i stal nierdzewna, sytuację dodatkowo pogorszył kryzys gospodarczy lat 30. Działalność ceramiczna Vallauris zaczęła się odradzać w latach 40. dzięki produkcji przedmiotów użytkowych, ale i artystycznych. Szczególne znaczenie $\mathrm{w}$ tym procesie odegrała rodzina Massier, zamieszkująca owe tereny od przełomu XIX i XX wieku ${ }^{3}$, oraz małżeństwo Ramie. Trzej bracia Massier - Clément, Delphin i Jerôme, którzy kontynuowali rodzinną tradycję ceramiczną, stali się prekursorami nowych technik dekoracyjnych takich jak - emaliowanie fajansu i użycie metalicznego połysku (ok.1886/1887), co dostrzeżono podczas Expositions Universelles w 1889 roku i nagrodzono złotym medalem. Atelier słynęło z nietypowych rozwiązań kolorystycznych oraz form dekoracyjnych, w tym zwierzęcych ${ }^{4}$. Stanowiło pewnego rodzaju szkołę, z której nauki czerpali lokali twórcy. Wśród licznych pracowni ceramicznych, ulokowanych na mapie Vallauris, szczególną rolę odegrało atelier Madoura, wprowadzając miasto $\mathrm{w}$ jego złoty wiek.

Pracownia Madoura została założona przez przybyłe z Lyonu małżeństwo - Suzanne i Georgesa Ramié, jej nazwa jest skrótem od słów: MAison-DOUly-RAmie, (czyli nazwisk Suzanne i Georgesa). Suzanne Douly ukończyła Ecole des Beaux-Arts de Lyon, w dziale dekoracji i ceramiki, początkowo trudniła się pracą w branży reklamowej w Cannes, jej mąż — Georges zajmował się zaś leśnictwem. W 1938 roku odkryli Vallauris, gdzie postanowili kupić dawną fabrykę Foucard-Jourdans. Ceramika produkowana przez Suzanne Douly szybko zyskała indywidualny rys, będąc połączeniem tradycyjnych form $\mathrm{z}$ jej osobistymi poszukiwaniami, co w szczególności wzbudziło zainteresowanie Pabla Picasso ${ }^{5}$. Każdy z pracowników Madoura posiadał swoje zadanie, Suzanne zajmowała się pracą koncepcyjną i wykonywaniem studiów przygotowawczych, Georges Ramié nadzorował wypalanie przez tokarza - Julesa Agarda, którego obowiązkiem było również określenie możliwości przeniesienia koncepcji rysunkowej do ceramiki. Wszystkie przedmioty, powstające w warsztacie Maudora, były fajansami wypalanymi w temperaturze około 980 stopni $^{6}$. Cześć obiektów powstawała na kole garncarskim, inne przy pomocy połączenia istniejących, samodzielnych części. Na przestrzeni lat z pracownią byli związany malarze i poeci, m.in.: Pablo Picasso, Marc Chagall ${ }^{7}$, Henri Mattise, Victor Brauner, Anton Prinner, Edouard Pignon,

3 Vallauris, cite d'argile, http://www.vallauris-golfe-juan.fr/Vallauris-cite-d-argile.html, [dostęp: 2.05.2017].

${ }^{4}$ La céramique artistique, http://www.vallauris-golfe-juan.fr/La-ceramique-artistique.html, [dostęp: 15.10.2017].

${ }^{5}$ Suzanne Ramie - biography, [w:] Art Deco Ceramic Glass Light http://www.artdecoceramicglasslight.com/makers/ramie-suzanne---madoura/rami-suzanne---madoura---biography, [dostęp: 03.05.2017].

${ }^{6} \mathrm{M}$. McCully, La transgression a l'oeuvre: Picasso, la ceramique et la mediterranee, [w:] Picasso Cote d'Azur, red. M. McCully, Paris 2013, s. 31.

${ }^{7}$ Marc Chagall odkrył ceramikę dzięki wyjazdowi na południe Francji, gdzie osiadł w 1949 roku po powrocie ze Stanów Zjednoczonych. Przez ponad dwadzieścia lat wykonał ok. dwustu dwudziestu unikatowych obiektów, takich jak: wazony, zdobione talerze, panele ścienne. Geniusz Chagalla pozwolił mu przyswoić potencjał materiału, ceramiki posiadają tę samą liryczną gęstość co obrazy malarskie. 
Jean Cocteau, czy Paul Éluard ${ }^{8}$. Mimo obecności wielu znakomitych postaci w Vallauris to przyjazd Picassa odnowił dynamikę gospodarczą, całkowicie zmieniając historię miejsca oraz na stałe wpisując się w pejzaż Lazurowego Wybrzeża ${ }^{9}$. Burmistrz miasteczka Paul Derigone pisał: „Dzięki Tobie upadający przemysł doświadcza rozwoju jak nigdy. Twoje imię sławi Vallauris na całym świecie $[\ldots]^{10,}$.

Picasso odkrył Vallauris w 1936 roku, gdzie przebywał w towarzystwie Paula i Nusch Éluard, powrócił tam dziesięć lat później z Francoise Gilot z powodu dorocznej wystawy wyrobów ceramicznych, perfum i kwiatów, która została ożywiona po wojnie przez André Baud. Jego uwagę zwróciło stoisko Suzanne i Georgesa Ramie, gdzie zobaczył małą głowę fauna i dwa byki ${ }^{11}$. Znajomość z państwem Ramie odnowił w 1947 roku, prezentując im na pierwszym spotkaniu po rocznej przerwie około pięćdziesiąt studiów. Znajomość szybko stała się tak zażyła, że od tego czasu niemalże codziennie przebywał w prowadzonym przez nich warsztacie, kontynuując współpracę aż do śmierci w $1973 \mathrm{roku}^{12}$. Na decyzję Picassa o opuszczeniu Paryża i powrocie do Vallauris wpłynęło wiele czynników. Hiszpan odnalazł na Lazurowym Wybrzeżu „swój krajobraz”, podróżując regularnie od 1919 roku do Antibes, Golfe-Juan czy Cap d'Antibes ${ }^{13}$. Pomiędzy 1920 a 1939 rokiem Picasso pięciokrotnie wyjeżdżał na Riwierę, w 1925 roku odbył także podróż do Monte Carlo ${ }^{14}$. Jak po latach wspomina Françoise Gilot - Picasso od dziecka znał historie Morza Śródziemnego, stanowiły one kawałek jego istoty ${ }^{15}$. Nie tylko śródziemnomorski klimat czy świadomość tradycji regionu przybliżały go do utęsknionej Hiszpanii, szczególny wpływ miała również ceramika. Artyście urodzonemu w Maladze znane były lokalne tradycje, średniowieczne hiszpańsko-mauretańskie wzory oraz kształty i funkcje poszczególnych naczyń.

Prowadzona przez małżeństwo Ramie pracownia Maudora wywarła duże wrażenie na Picassie już podczas pierwszej wizyty. Dom przykryty dachem z płytek ceramicznych, ganek z nadprożami i belkami stropowymi z litego drewna, to wszystko przypominało architekturę hiszpańskich wiosek ${ }^{16}$. Swoboda twórcza, którą odnalazł w atelier, przyczyniła się do połączenia motywów ceramicznych z terenów Hiszpanii, Grecji, Rodos, Azji Mniejszej oraz tych zaczerpniętych z eksponatów podziwianych w Luwrze, co doprowadziło do powstania całkowicie nowych rozwiązań formalno-artystycznych. Mimo tego, że Picasso poświęcił więcej uwagi ceramice dopiero podczas dłuższego pobytu na Lazurowym Wybrzeżu, od lat 40. zawsze należała ona do szerokiego wachlarza jego zainteresowań, co podkreśla również jego współpraca z licznymi ceramikami w okresach paryskich.

${ }^{8}$ S. Haro Gonzalez, Picasso, céramiste à Vallauris, [w:] Picasso, céramiste à Vallauris: pièces uniques, red. S. Benadretti-Pellard, [Paris] 2004, s. 38.

${ }^{9} \mathrm{O}$ roli obecności Picassa na Lazurowym Wybrzeżu świadczą powstające w miastach muzea, wznoszone ku czci artysty. Stanowią one dziś jedną z ważniejszych atrakcji turystycznych.

${ }^{10}$ M. N. Delorme, Picasso ,ouvrier de la terre et du feu”, [w:] Picasso, céramiste à Vallauris, s. 34 .

${ }^{11}$ Tamże.

${ }^{12} \mathrm{~S}$. Haro Gonzalez, Picasso, céramiste à Vallauris, s. 21.

${ }^{13}$ Brassai, Rozmowy z Picassem, thum. i posł. opatrzył Z. Florczak, Warszawa 1979, s. 182.

${ }^{14}$ Picasso odbył podróż do Monte Carlo wraz z swoją żoną Olgą Chochłową na zaproszenie Siergieja Diagilewa; za: McCully, Picasso et ses etes sur la Cote d'Azur, [w:] Picasso Cote d'Azur, s. 13.

${ }^{15}$ M. McCully, Picasso et ses etes sur la Cote d'Azur, [w:] Picasso Cote d'Azur, s. 29.

${ }^{16}$ Tamże, s. 30. 
Hiszpan swoje pierwsze prace ceramiczne realizował w atelier Francisca Durrieu de Madrón (zwanego: Paco Durrio) na Montmartre w latach 1901-1906. Zostały one wykonane pod silnym wpływem ceramiki Durrio oraz jego przyjaciela Gaugina ${ }^{17}$. Ceramika Gaugina odegrała niezwykle istotną rolę w twórczości Picassa. Jej wpływ widoczny jest również w pracach, realizowanych po śmierci artysty m.in. dzięki rozmaitym wydawnictwom, prezentującym jego prace. W latach 20 . Picasso nawiązał twórczą znajomość z Josepem Llorensem i $\operatorname{Artigas}^{18}$ - katalońskim ceramikiem przebywającym wówczas w mieście świateł, zaś na 1929 rok datuje się stworzone we współpracy z Jeanem van Dongenem dwie wazy ceramiczne. Naczynia, przechowywane dziś w paryskim muzeum Picassa, zostały udekorowane motywem kąpiących się kobiet oraz rybami. Według sygnatury autorami obiektów są obydwaj artyści ${ }^{19}$.

W lipcu 1946 roku Picasso wraz z Françoise Gilot zamieszkał na terenie warsztatu Louisa Forda w Golfe-Juan. Jak utrzymują niektórzy badacze, to w tym czasie dzięki przypadkowemu spotkaniu na plaży pochodzącego z Polski fotografa - Michała Smajewskiego (Michela Simy) ${ }^{20}$ — malarz na nowo odkrył atelier Suzanne i Georgesa Ramie $^{21}$. Informacja ta nie znajduje potwierdzenia w źródłach, ale pewne jest to, że Sima towarzyszył Hiszpanowi podczas jego pracy w Chateau d'Antibes od 1946 roku $^{22}$ fotografując go także później $(1948,1950)$ w atelier Madoura. Picasso i Sima poznali się w 1936 roku w Paryżu dzięki poecie i ich wspólnemu przyjacielowi, Robertowi Desnosowi. Początkujący artysta, pochodzący z żydowskiej rodziny mieszkającej w Słonimiu wyruszył do Paryża w 1929 roku, gdzie zamieszkał u wuja Chapiro, który od jakiegoś czasu prowadził zakład stolarski w Montreuil ${ }^{23}$. Mający 17 lat Smajewski rozpoczął studia na Académie de la Grande Chaumière, gdzie pobierał nauki do 1932 roku. Od 1933 r. kontynuował pracę w atelier rzeźbiarza Fetu, w latach 1934-1935 był asystentem w pracowni Ossipa Zadkine'a ${ }^{24}$, a od 1937 r. był uczniem w pracowni Con-

${ }^{17} \mathrm{H}$. Theil, Les vases plastiques de Picasso. Les sources d'inspiration antiques, [w:] Picasso céramiste et la Méditerranee, red. B. Gaudichon, J. Matamoros, [Paris] 2013, s. 71-73.

18 Josepe Llorensen i Artigas, kataloński ceramik. We współpracy z Joanem Miró stworzył Ścianę stońca i Ścianę księżyca zdobiącą budynek UNESCO w Paryżu (1957-1958). W latach 20. związany z kręgiem Braque'a, Buñuela i Picassa; Fundació Privada - Tallers Josep Llorens Artigas, http://www.fundacio-artigas.com/index.php?mnu=fundacion\&amp;idi=es, [dostęp: 30.06 . 2017].

${ }^{19}$ B. Gaudichon, J. Matamoros, Avant Vallauris, Vallauris, [w:] Picasso céramiste et la Méditerranee, s. 24.

${ }^{20}$ Michel Sima, właśc. Michał Smajewski, (1912-1987), podstawowych informacji na temat artysty dostarcza francuskojęzyczna oraz anglojęzyczna literatura, która prezentuje jedynie rys biograficzny twórcy. Bogaty zbiór archiwaliów dotyczący Michela Simy, przechowywany w Archiwum Rodziny Smajewskich, jest poddany badaniom prowadzonym przez autorkę. Publikacje wzmiankujące Smajewskiego, m.in.: D. de la Souchère, Picasso in Antibes, London 1960; Francis Picabia. Ecritures et dessins. Rencontres avec Pierre-André Benoit, Henri Goetz, Christine Boumeester, Michel Sima, red. P. Belfond, Carcassonne 2003; M. Haworth-Booth, The artist as subject. The photographs of Michel Sima, Apollo 1997 nr 428, s. 3-11; E. Billeter, Michel Sima. Atelier d'artiste, Gent 2008.

${ }^{21}$ M. McCully, La transgression a l'oeuvre, s. 30.

22 J. L. Andral, Epilogue, [w:] Picasso Cote d'Azur, s. 136. 2015).

${ }^{23}$ Na podstawie wywiadu z Pierre Smajewskim przeprowadzonego przez autorkę (Francja

${ }^{24}$ Ossip Zadkine (1890-1967), pochodzący z Witebska rzeźbiarz czynnie działający w Paryżu. Jeden z członków École de Paris. Tworzył wielowymiarowe rzeźby, głównie z metalu 
stantina Brâncuşiego ${ }^{25}$. W latach 30 . dla zarobku wykonywał dla paryskich agencji prasowych fotografie reportażowe, dokumentujące takie wydarzenia jak przemówienie francuskiego polityka Leona Bluma z okazji 14 lipca czy wystawę surrealistów z 1937 roku $^{26}$. To czas, kiedy Smajewski poznał Cocteau, Éluarda czy Picabię, uczestniczył w ich niedzielnych spotkaniach poetyckich, zyskując przydomek artystyczny: Sima, jako anagram słowa: amis — przyjaciel. W 1940 roku zamieszkującego w Vallauris Smajewskiego wcielono do Camp de Coëtquidan — francuskiego obozu wojskowego położonego w Bretanii, zaś 2 sierpnia 1942 roku, jako Żyda, aresztowano i uwięziono w Nicei. Artysta został oddany w ręce Niemców i przetransportowany do obozu w Drancy. Więźniowie oczekiwali tam na transport do obozu zagłady. Nazwisko Smajewskiego figuruje na liście transportowej deportowanych do KL Auschwitz z 29 listopada 1942. Pierwsza selekcja transportu nastąpiła w Kędzierzynie-Koźlu (Blechhammer), gdzie Sima prawdopodobnie został zatrudniony, nie wiadomo jednak, w jakim charakterze $^{27} .9$ maja 1945 roku ciężko chory artysta opuścił obóz, wyjeżdżając na Lazurowe Wybrzeże ${ }^{28}$, gdzie w 1946 roku ponownie spotkał Picassa. To dzięki ingerencji Hiszpana, wyniszczony psychicznie oraz fizycznie Sima na nowo postanowił zająć się fotografią, a później również ceramiką i rzeźbą. Artyści dzielili atelier w pomieszczeniach Château d'Antibes, udostępnionych Smajewskiemu przez jego wieloletniego przyjaciela - Romualda Dor de la Souchère - kuratora zamku, profesora francuskiego, greki i łaciny w Liceum Carnot w Cannes. Posiadanie pracowni w tym miejscu miało szczególne znaczenie dla Picassa, gdyż przed dwudziestu laty, kiedy wojsko wystawiło zamek na sprzedaż, o mało nie stał się on jego własnością. Ubolewał, że wojsko wolało budynek sprzedać miastu niż osobie prywatnej. Dodatkowo przestronne i słoneczne pomieszczenia Château d'Antibes dawały artyście możliwość swobodnej pracy, co było dla niego niezwykle istotne i nie ograniczało jego działań twórczych jak w 1923 roku, kiedy zamieszkiwał w Cap d'Antibes gdzie mógł wykonywać jedynie prace rysunkowe. W 1946 roku w Château powstał cykl fotografii dokumentujących prace Picassa nad jego najważniejszym dziełem z tego okresu — muralem Joie de Vivre. Rysunki i obrazy Picassa, powstałe w przestrzeniach zamku Grimaldi, przywołują wspomnienia starożytnych krajobrazów Antipolis-Antibes, przepełnione są nastrojem arkadii, w której zamieszkują brodate fauny, minotaury czy zwiewne nimfy. Jak wspomina Dor de la Souchère, Sima towarzyszył artyście niemalże każdego wieczora, tworząc „raporty fotograficzne”, dokumentujące pracę i dzieło mistrza ${ }^{29}$. Na niektórych

i drewna. Wystawiał na Salonie Jesiennym i Salonie Niezależnych. Jego dorobek opiewa na ponad czterysta rzeźb oraz kilka tysięcy rysunków, akwarel oraz grafik.

${ }^{25}$ Constantin Brâncuși (1876-1957), rumuński rzeźbiarz działający we Francji. Twórca abstrakcji organicznej w rzeźbie. Autor takich dzieł, jak: Ptak w przestrzeni, Śpiąca muza, Pocałunek czy Niekończaca się kolumna.

${ }^{26}$ P. E. Smajewski, Michel Sima, sculpteur et photographe. Rencontres avec Francis Picabia, [w:] Ecritures et dessins, s. 3-4, 8.

${ }^{27}$ Informacje uzyskane przez autorkę z Archiwum Państwowego Muzeum Auschwitz-Birkenau.

${ }^{28}$ Niestety nie zachowały się żadne informacje, mówiące o tym, że wybór miejsca był decyzją Simy, nie wiadomo również, czy podróż podjął na własną rękę, czy może znalazł się w grupie byłych więźniów transportowanych wówczas na południe Francji. Daty deportacji oraz opuszczenia obozu przez Michela Simę potwierdza Carte de déporté politique oraz karta wydana przez Union Nationale des Associations de déportés internés et familles de disparus, przechowywane w archiwum rodziny Smajewskich; tłum. A. Chwiałkowska.

${ }^{29}$ E. Billeter, Michel Sima, s. 19-21. 
zdjęciach Picasso zostaje ukazany bezpośrednio przy pracy, na innych, podążając za wytycznymi Smajewskiego, przyjmuje najróżniejsze pozy wokół obrazów i ceramik. Bogatą kronikę artystycznych działań Hiszpana na Lazurowym Wybrzeżu uzupełnia cykl fotografii, wykonanych przez pochodzącego z Polski twórcę w atelier Madoura.

Spotkanie z Picassem po opuszczeniu obozu koncentracyjnego w znacznym stopniu wpłynęło na dalszą drogę Michela Simy. Artysta nie tylko przyjął rolę dokumentalisty Picassa czy Matisse'a, twórcy portretów drugiej Szkoły Paryskiej, ale również na nowo zajął się rzeźbą i ceramiką. Na obiektach z lat 40. i 50. widać wpływ lokalnych tradycji, paryskich nauczycieli oraz rzeźb i ceramik, które Sima prawdopodobnie oglądał, zamieszkując w mieście świateł. Ceramika Smajewskiego w dużym stopniu została ukształtowana również dzięki doświadczeniu i twórczym eksperymentom hiszpańskiego mistrza. Śródziemnomorskie tradycje szybko znalazły wyraz w ceramicznych kompozycjach, stworzonych przez obydwu artystów. Na podłużnych talerzach, wazonach czy dzbanach rysują się radosne motywy, niewystępujące w paryskich okresach Picassa ani w rzeźbie Smajewskiego. Naczynia pokrywają sceny pełne nimf o wydłużonych ciałach, flecistów i centaurów. Swoje miejsce znalazły również przedstawienia ukazujące ulubioną rozrywkę Hiszpana — walki byków ${ }^{30}$.

Podczas pobytu na Lazurowym Wybrzeżu Picasso wiele uwagi poświęcał ceramice, przyniosła ona doświadczenie pracy w nowym materiale, którego zakrzywione powierzchnie pozwoliły mu zyskać kolejne pomysły, przydatne w malarstwie, rzeźbie czy asamblażu ${ }^{31}$.

Autor Joie de Vivre wykorzystywał tradycyjne śródziemnomorskie elementy, takie jak grawerowanie, nacięcia czy bogatą kolorystykę, co wraz z jego osobistymi poszukiwaniami pozwoliło skierować pracę z owym materiałem na inną płaszczyznę. Sztuka Picassa, nastawiona na poszukiwanie nowych możliwości, niosła ze sobą kolejne rozwiązania techniczne i ikonograficzne, oddalając się od dekoracyjności w kierunku myśli koncepcyjnej. Innowacyjne stało się wykorzystanie powierzchni i objętości naczynia oraz podstawowych elementów ceramiki.

Jedne z pierwszych dzbanów, które zostały wykonane przez Picassa, takie jak Trois nus (1947-1948) czy Femme (1947-1948), cechuje podkreślenie kształtu naczynia oraz wyraźna kolorystyka. Ciała kobiecych postaci zostały dopasowane do formy garnka, kompozycje są oszczędne w wyrazie, formy niezwykle uproszczone. Dodatkowym elementem, często wykorzystywanym przez artystę, jest grawerunek, co możemy dostrzec m.in. na dzbanku Oiseau et fleurs (1948). Latem 1947 roku powstały pierwsze zoomorficzne i antropomorficzne naczynia, będące połączeniem kilku pustych kształtów, które wcześniej zostały wykonane na kole garncarskim. O pracy koncepcyjnej artysty silnie mówią wykonywane przez niego rysunki. Pokazują, jak Picasso dekonstruuje podstawowe kształty waz, zestawia różne komponenty, łączy naczynia użytkowe i elementy figury ludzkiej. Na połączenie w jedność przedmiotu użytkowego i tego o wyraźnie zaznaczonej funkcji plastycznej niewątpliwy wpływ miały tradycyjne hiszpańskie naczynia oraz grecka ceramika, zgromadzona w Luwrze. W 1900 roku do kolekcji muzealnej przekazano Sirène (VII wiek p.n.e.) oraz Sirène coiffée d'un Polos (550 p.n.e.), które Picasso musiał oglądać, przebywając po 1901 roku w dziale antyków greckich, etruskich i rzymskich. Obydwa naczynia tworzą hybrydowe stwory, będące

${ }^{30}$ Jak wspomina François Gilot w Żyć z Picassem, uczestnictwo w niedzielnych walkach byków było pewnego rodzaju rytuałem, do którego malarz przygotowywał się w specjalny sposób; M. McCully, La transgression a l'oeuvre, s. 34.

${ }^{31}$ M. McCully, Les ceramiques et la Cote d'Azure, [w:] Céramiques de Picasso, s. 16. 
połączeniem ludzkiej twarzy, syreny oraz ptaka ${ }^{32}$. Na jednym z pierwszych rysunków artysty, powstałych w tym czasie, pojawia się również botijo - tradycyjne hiszpańskie naczynie w kształcie koguta, służące do przechowywania wody ${ }^{33}$. Na ostatnie dni września 1947 roku datuje się ilustracje, które prezentują nowy styl, dominujący od tego czasu w jego ceramice, Picasso rysuje mające swe źródło w starożytności - wazę, amforę i lekyt ${ }^{34}$, które zostają poddane wielokrotnym przekształceniom.

Owocem eksperymentów, prowadzonych przez Hiszpana, było również nowatorskie podejście do koloru, co przejawiało się między innymi w złamaniu tradycyjnego zestawienia barw, występujących do tego czasu w ceramice. Kolor pojawił się również na glinianych rzeźbach, wykonanych zimą 1948 roku w Paryżu. Niewątpliwy wpływ na pojawienie się barw na obiektach miały śródziemnomorskie tradycje, grecka ceramika oraz odrodzenie się polichromii w XIX wieku ${ }^{35}$.

W rysunkach z 24 września 1947 roku pojawiają się zoomorficzne naczynia w kształcie ptaków - jastrzębi, kondorów czy sów, w swej formie nawiązują do hiszpańskiego botijo. Zwierzęta, które były ulubionymi mieszkańcami atelier przy rue Grand Augustine, znajdują stałe miejsce w twórczości artysty. Często wykorzystywanym motywem jest również postać kobieca, na 1947-1948 rok datowana jest wykonana przez Picassa Tanagra, czyli figurka nawiązująca w swej nazwie do powstających w Beocji statuetek, ukazująca młodą niewiastę. Grawerowana i malowana amfora przedstawia postać trzymającą dzban, co wskazuje na inspiracje kartami pocztowymi, które Picasso musiał kupić podczas jednego z wyjazdów do Hiszpanii. Korpus naczynia został przekształcony w kobiece ciało, zaś uszy pełnią funkcję rąk. Biała polichromia posiada grawerowane elementy, przy pomocy których zaznaczono nogi, piersi, szyję oraz twarz.

Niewątpliwie źródeł inspiracji, kształtujących ceramikę Picassa, było wiele. Powracając do Vallauris w 1947 roku, znał ceramikę Gaugina i prawdopodobne L'Encyclopedie photographique de l'art ${ }^{36}$, której drugi i trzeci tom stanowily bogaty materiał ikonograficzny. Tomy ilustrowały kolekcję dzieł zebranych w Luwrze, który od przejęcia kolekcji Campana w 1861 roku posiadał największe zbiory ceramiki greckiej. Picasso od 1901 roku odwiedzał regularnie starożytne kolekcje, Ardengo Soffici — pisarz i malarz - wspominał ich spotkania w 1905 roku, kiedy Hiszpan studiował obiekty w dziale egipskim, orientalnym, greckim i rzymskim ${ }^{37}$. Powstała w 1949 roku Femme à la mantille zdradza wyraźny wpływ greckich kor, czyli popularnych w okresie archaicznym posągów. Zarówno kora jak i kobieca postać, stworzona przez Picassa, posiadają blokową formę, ręce umieszczone w obrębie ciała, obydwie figury zostały także odziane w długie szaty i obcisły kaftanik na wysokości klatki piersiowej. Twórca pokrył powierzchnie wazy dodatkowo kolorem ochry i czerni, zaznaczając w wyraźny sposób ubiór, twarz, włosy oraz nakrycie głowy, czyli mantylę, która stanowi odmianę welonu wycinanego z koronki lub jedwabiu. Jest ona element ludowego stroju, noszonego przez kobiety w niektórych regionach Hiszpanii.

32 Louvre. Sirène coiffée d'un polos, http://cartelfr.louvre.fr/cartelfr/visite?srv=c ar_not_frame\&idNotice=6407\&langue=fr, [dostęp: 30.06.2017].

${ }^{33}$ H. Theil, Les vases plastiques, s. 64

${ }^{34}$ Tamże, s. 65.

${ }^{35}$ M. McCully, La transgression a l'oeuvre, s. 31.

${ }^{36}$ L'Encyclopedie photographique de l'art — została wydana w kilku tomach w Paryżu w latach 1936-1938.

${ }^{37} \mathrm{H}$. Theil, Les vases plastiques, s. 71-73. 
Zbiór ceramik autorstwa Michela Simy tworzy kilkanaście obiektów, które zostały wykonane w atelier Madoura w Vallauris. Przedmioty można podzielić na ceramikę dekoracyjną oraz użytkową, są to: talerze, medaliony, plakietki, dzbany, wazy czy świeczniki. Niestety, jedynie niektóre obiekty posiadają sygnaturę oraz datę powstania, co znaczenie utrudnia ich chronologiczne uporządkowanie. Nie zachowały się również żadne szkice rysunkowe, które potwierdzałyby twórczą drogę artysty. Sima czerpał inspiracje z lokalnej ceramiki z Vallauris, prehistorycznych i starożytnych naczyń oraz dzieł autorstwa Picassa, Matisse'a i Gauguina. Podążając za hiszpańskim mistrzem i przyjacielem, którego ceramiczna twórczość wywarła na niego znaczący wpływ, wykorzystuje wyraźną kolorystykę, grawerunek oraz nacięcia, odwołuje się do podobnych rozwiązań formalnych, wprowadzając jednocześnie indywidualne wzorce, również sam sposób przedstawienia jest zupełnie inny. Tak jak Matisse tworzy linearny rysunek, wiedziony giętką, pełną finezji liną, czy sięga do tych samych antycznych inspiracji, co Gauguin. Jedną z najliczniejszych grup są malowane talerze, niektóre pozbawione dekoracji, ale zwracające uwagę swą syntetyczną formą, nawiązującą do stworzeń morskich. Na innych rysują się linearnie prowadzone sylwetki kobiet, mężczyzn, zwierząt i hybrydalnych stworów. Szczególnie interesujący jest jeden talerz, na którym w nieokreślonej, niebiesko-zielono-czarnej przestrzeni przedstawiono dwie nagie postacie. Anatomie potraktowano umownie, mimo uproszczenia figury nawiązują do posągów greckich kor i kurosów. Postać męska ma wyraźne rozbudowane ramiona i zwężone biodra, zaś kobieca podkreśloną talię i uwydatniony biust. Ciała przedstawiono przy pomocy płasko kładzionej, jednobarwnej plamy, całość została obwiedziona wyraźnym konturem. Postacie są ukazane w swobodnym, niczym nieskrępowanym, pełnym radości ruchu, co wraz z kolorystyką i linearnym konturem podkreśla dialog z Tańcem Matisse'a. Forma jest jednakże nieco inna, postacie nie są tancerzami, u których ukazano mięśnie, ich nieidealizowane ciała wskazują prowadzone przez Simę poszukiwania dążące do podkreślenia pierwotnego wyrazu. Michel Sima, budując na talerzach swe ceramiczne narracje, korzysta również z kolorystyki greckiej ceramiki, odwołuje się do stylu czarno i czerwono figurowego. Swobodnie kształtowane proporcje ludzkiego ciała są widoczne także na wazach i dzbankach. Na niektórych z nich jak na jednokolorowym dzbanie o owalnym kształcie pojawia się ryta, typizowana męska oraz kobieca sylwetka. Wydłużone i wysmuklone postacie zostały przedstawione w swobodnym ruchu, wszystkie są ukazane z profilu, w minimalny, ale w znaczący sposób zostały zaznaczone twarze: oczy, włosy, usta, nosy oraz elementy anatomiczne, takie jak: pośladki, brzuchy czy klatka piersiowa. Smajewski, podążając za Picassem, przekształca ludzkie ciało, zmieniając i dostosowując je do kształtu naczynia, niejako uprzedmiotawia ciało, jako formę człowieka pozbawia go indywidualności. Kobiece sylwetki, aby dostosować się do form naczyń, które mimo przekształcenia nawiązują do prehistorycznych czy starożytnych, posiadają wydłużone szyje, podkreślające kształt olpe, czy wydatne biodra uwidaczniające konstrukcje amfor. Szczególnie warte uwagi jest naczynie o gruszkowatej formie, przypominające alabastron typu korynckiego, czyli z uchem. Niestety, ze względu na uszkodzenie górnej części, nie możemy zidentyfikować kształtu wylewu i jednocześnie w pełni odczytać przedstawionej twarzy. Białe, emaliowane naczynie zdobi ryta, kobieca sylwetka, ujęta w niezwykle subtelnym ruchu. Wpływ hiszpańskiego mistrza jest widoczny również $\mathrm{w}$ zestawieniu naczynia, przypominającego grecki psykter $\mathrm{z}$ jednym $\mathrm{z}$ wazonów Simy ${ }^{38}$. W kształt emaliowanego na czarno psyktera, Picasso wpisał białe, potraktowane linearnym konturem kobiece ciało, które wypełnia całą jego przestrzeń. Do

\footnotetext{
${ }^{38}$ Olpe, naczynie do przechowywania olejków i oliwy.
} 
podobnego zabiegu odwołał się Sima, malując kobietę w czarno-niebieskiej pustce. Mimo nieustającej inspiracji ceramiką Hiszpana, Smajewski całkowicie inaczej postrzega ludzkie ciało niż Picasso, nie skupia się na malarskim ukazaniu twarzy czy dłoni, interesujący jest dla niego człowiek w kontekście przestrzeni i ruchu. Minimalną inspirację stanowią również zwierzęta, które autor Joie de Vivre wielokrotnie wpisywał w ceramiczne formy. Ponadto Michel Sima odmiennie traktuje kształt naczynia. Nie tylko łączy różne elementy, jak robił to Picasso, ale również poszukuje indywidualnych rozwiązań, które integruje z kształtami popularnymi w prehistorycznej kulturze cucuteni ${ }^{39}$. Figuratywna ludzka postać stanowi stały element ceramik Gauguina, łączy ikonograficzne motywy bretońskie oraz te zapożyczone z regionów Peru czy Martyniki, obecne w pracach artysty. Gauguin nawiązuje do formy tradycyjnych starożytnych naczyń, takich jak: hydria ${ }^{40}$, pyksis ${ }^{41}$, czy tworzy hybrydy będące połączeniem lub pomnożeniem pojedynczych elementów, wzbogaconych częściami figuratywnymi. Z jego eksperymentów czerpie Picasso oraz Sima. Postać ludzka zapełnia powierzchnię przedmiotów Gauguina niczym płaskorzeźba, stanowi element dekoracyjny lub główną, rzeźbiarską formę całego przedmiotu jak w garnku w formie głowy bretonki. Prace Gauguina wystawiane jeszcze za jego życia nie cieszyły się popularnością wśród krytyków, ale mimo to były prezentowane w paryskich galeriach. Sima z pewnością znał owe ceramiki z opowieści Picassa, być może widział je osobiście. Niektóre obiekty Smajewskiego nawiązują do formalnych rozwiązań stosowanych przez Gauguina. Na 1886 rok datuje się garnek z głową na krawędzi oraz słój z czterema nogami, które mogły stanowić inspiracje podczas pracy pochodzącego z Polski artysty nad owalnym, dwuczęściowym naczyniem (puzderkiem?) z pokrywą, na szczycie której umieszczono wydłużoną szyję i głowę kobiety. Artysta wykonał całą serię kulistych naczyń z różnymi wariantami elementów dekoracyjnych, czasami jest to kobieca postać, umieszczona na górnym zamknięciu, innym razem zostaje ona przetworzona w uproszczoną, geometryczną figurę $\mathrm{w}$ formie uszu, za które podnosi się naczynie, podobne rozwiązania stosowali rzemieślnicy kultury cucuteni. Niezwykle interesujące jest naczynie, przechowywane w kolekcji rodziny Smajewskich, które kształtem przypomina kyliks ${ }^{42}$, z pokrywą jednakże jest nieco głębsze i nie posiada uchwytów do trzymania. Frontalną część zdobi ryta, syntetyczna twarz nawiązująca do rzeźby iberyjskiej i sumeryjskiej, tak ważnej w twórczości Picassa i Gauguina i licznych artystów przełomu XIX i XX wieku. Na chropowatej powierzchni rysują się duże, migdałowe oczy, wąski nos oraz ledwo zaznaczone usta, cały rysunek stanowi linearną strukturę. Niestety, ze względu na nieliczną liczbę sygnatur i dat, umieszczonych jedynie na niektórych talerzach, niemożliwe jest jednoznaczne określenie, kiedy Sima przebywał w atelier Madoura jako ceramik, a nie fotograf, dokumentator pracy Picassa. Sygnatury umieszczone na talerzach wskazują grudzień 1949 roku oraz 1950 rok. Atelier Madoura było miejscem, które często odwiedzali wybitni artyści, pisarze i poeci, gościł tam po powrocie ze

${ }^{39}$ Kultura Cucuteni, neolityczna kultura rozwijająca się na terenach Rumunii od ok. 4500 p.n.e. Być może Michel Sima zapoznał się z obiektami cucuteni podczas pobytu w Paryżu lub zainteresował się nimi dzięki Brâncușiemu, w którego atelier pobierał nauki. Wątek ten podlega dalszym badaniom autorki.

${ }^{40}$ Hydria, naczynie służące do przenoszenia i przechowywania wody.

${ }^{41}$ Pyksis, naczynie w formie cylindrycznej służące do przechowywania biżuterii i artykułów toaletowych.

${ }^{42}$ Kyliks, czara służąca do picia, jedno z najpiękniejszych naczyń ceramicznych. Jego forma ulegała licznym przekształceniom. 
Stanów Zjednoczonych Marc Chagall (1948), Jacques Prévert (1949) ${ }^{43}$, a także Jean Cocteau czy Georges Braque (1953) ${ }^{44}$. Wszystkie z wymienionych powyżej osobistości przebywały w atelier w towarzystwie Picassa, co uwieczniali na fotografiach tacy artyści jak Lee Miller, Pierre Manceta, Robert Doisneau czy Michel Sima. Długotrwała praca Picassa w atelier Madoura spowodowała zastój w produkcji, przeznaczonej na sprzedaż, przez co w ramach rekompensaty zgodził się na dodatkową produkcję niektórych swoich dzieł w ograniczonej ilości. Przyjmuje się, że od lipca 1947 do października 1948 wyprodukował około dwóch tysięcy obiektów ${ }^{45}$, zaś do 1971 roku powstało ich trzy i pół tysiąca. W 1953 roku Picasso spotkał w atelier Jacqueline Roque, którą poślubił, przeprowadzając się do Mougins. Twórca kontynuował pracę ceramiczną aż do śmierci w1973 roku $^{46}$.

W 2014 świat sztuki obiegły wieści o fatalnym stanie pracowni, w której napisano historie dwudziestowiecznej ceramiki. Przez niepokojące informacje, pojawiające się $\mathrm{w}$ francuskiej prasie, lokalne władze podjęły starania i pracownię wykupiono $\mathrm{z}$ rąk rodziny Ramié, po czym przystąpiono do jej remontu. Dziś w dwupoziomowym, odnowionym budynku znajdują się dwie ekspozycje: stała i czasowa. Sale wystaw zmiennych regularnie służą pokazom Biennale Ceramiki, organizowanego w Vallauris. Wystawa stała upamiętnia obecność Picassa i Chagalla, niestety zapomniano przy tym o licznych twórcach, którzy przyczynili się do wykreowania nowej historii tego miejsca. Sprawia to, że wielu znakomitych fotografów, takich jak Robert Doisneau, David Douglas Duncan, Gjon Mili, Edouard Quinn czy Michel Sima, zostaje częściowo pozbawionych indywidualnej pozycji, jako artyści stając się jedynie dokumentatorami Picassa. Odbiorca, patrząc na fotografię, widzi pochodzącego z Hiszpanii twórcę, jedynie nieliczni zastanawiają się nad nazwiskiem autora, którego zdjęcie mogą oglądać. Niektórzy, tak jak Michel Sima, nie tylko uwieczniali procesy, toczące się w Atelier Madoura, ale również prowadzili indywidualną działalność artystyczną, kontynuując ceramiczne tradycje prehistoryczne, starożytne, lokalne oraz motywy i rozwiązania powstające w pracowni (np. wzorce przejęte od Picassa). Przywołanie artystów, którzy dziś nie znaleźli swego miejsca na stałej ekspozycji, pełniłoby nie tylko funkcję kommemoratywną, ale również pozwoliłoby wskazać kontynuację i rozwój tradycji czy stosowanych w ceramice rozwiązań artystycznych i formalnych, stanowiąc jednocześnie dużą wartość dla badań nad ceramiką. Brak miejsca dla Michela Simy w Atelier Madoura wywołuje rozczarowanie, pozostawiając nadzieję, iż wciąż uzupełniana historia sztuki znajdzie dla artysty należne mu miejsce.

${ }^{43}$ Obecność w Atelier Madoura w 1949 roku potwierdza fotografia wykonana przez Pierre Manceta.

${ }^{44}$ Braque odwiedzał atelier również w 1954 roku, o czym świadczy fotografia autorstwa Lee Miller.

${ }^{45}$ B. Gaudicho, J. Matamoros, Picasso, ceramiste a Vallauris, Madoura, [w:] Picasso céramiste et la Méditerranee, s. 24.

${ }^{46}$ Picasso w atelier Madoura pojawił się ostatni raz w 1971 roku, jednakże ceramiką zajmował się do śmierci w 1973 roku. 


\section{LITERATURA}

A. d'Agliano, Ceramika. Wiek XIX, [w:] Ceramika XV-XX wieku, red. M. Cebo-Foniok, Warszawa 1998;

J. L. Andral, Epilogue, [w:] Picasso Cote d'Azur, red. M. McCully, Paris 2013;

E. Billeter, Michel Sima. Atelier d'artiste, Gent 2008;

Brassai, Rozmowy z Picassem, tłum. i posł. opatrzył Z. Florczak, Warszawa 1979;

La céramique artistique, http://www.vallauris-golfe-juan.fr/La-ceramique-artistique.html, [dostęp: 15.10.2017];

M. N. Delorme, Picasso „ouvrier de la terre et du feu”, [w:] Picasso, céramiste à Vallauris: pièces uniques, red. S. Benadretti-Pellard, Paris 2004;

Fundació Privada - Tallers Josep Llorens Artigas, http://www.fundacio-artigas. com/index.php?mnu=fundacion\&amp;idi=es, [Dostęp: 30.06.2017];

Gaudicho, J. Matamoros, Avant Vallauris, Vallauris, [w:] Picasso céramiste et la Méditerranee, red. B. Gaudichon, J. Matamoros, Paris 2013;

-, Picasso, ceramiste a Vallauris, Madoura, [w:] Picasso céramiste et la Méditerranee, red. B. Gaudichon, J. Matamoros, Paris 2013;

S. Haro Gonzalez, Picasso, céramiste à Vallauris, [w:] Picasso, céramiste à Vallauris: pièces uniques, red. S. Benadretti-Pellard, Paris 2004;

M. Haworth-Booth, The artist as subject. The photographs of Michel Sima, Apollo $1997 \mathrm{nr} 428$;

Louvre. Sirène coiffée d'un polos, http://cartelfr.louvre.fr/cartelfr/visite?srv=car_not_frame\&id Notice $=6407 \&$ langue $=$ fr, [Dostęp: 30.06 .2017$]$;

M. McCully, Les ceramiques et la Cote d'Azure, [w:] Céramiques de Picasso, red. M. McCully, Paris 1999;

—, Picasso et ses etes sur la Cote d'Azur, [w:] Picasso Cote d'Azur, red. M. McCully, Paris 2013;

—, La transgression a l'oeuvre: Picasso, la ceramique et la mediterranee, [w:] Picasso Cote d'Azur, red. M. McCully, Paris 2013;

P. E. Smajewski, Michel Sima, sculpteur et photographe. Rencontres avec Francis Picabia, [w:] Francis Picabia. Ecritures et dessins. Rencontres avec Pierre-André Benoit, Henri Goetz, Christine Boumeester, Michel Sima, red. P. Belfond, Carcassonne 2003;

D. de la Souchère, Picasso in Antibes, London 1960;

Suzanne Ramie - biography, [w:] Art Deco Ceramic Glass Light http://www.artdecoceramicglasslight.com/makers/ramie-suzanne---madoura/rami-suzanne---madoura---biography, [Dostęp: 03.05.2017]

H. Theil, Les vases plastiques de Picasso. Les sources d'inspiration antiques, [w:] Picasso céramiste et la Méditerranee, red. B. Gaudichon, J. Matamoros, Paris 2013;

Vallauris, cite d'argile, http://www.vallauris-golfe-juan.fr/Vallauris-cite-d-argile.html, [Dostęp: 2.05.2017].

\section{ARTISTIC FRIENDSHIP AT THE MADOURA STUDIO: MICHEL SIMA AND PABLO PICASSO}

The article discusses numerous significant trends of $20^{\text {th }}$-century art and aims to complement the extensive sources concerning the activity of Poles in France. It focuses on one of the most important and now largely forgotten pottery workshop of the French Riviera, the Madoura Studio. The article discusses the artists connected with this site, their works and the influence of Pablo Picasso on the economic situation of Vallauris. It also explores the artistic friendship between Pablo Picasso and Polish artist Michel Sima (Michał Smajewski). It reveals obscure facts from Sima's life and explores fragments of his abundant artistic legacy, which is stored in the private archives of his family. The author of the article makes an attempt to systematize and analyze Smajewski's ceramic works and, most significantly, to demonstrate that he was not merely a man documenting Picasso's creations but an important artist of the École de Paris in his own right.

KEY WORDS: Michel Sima; Pablo Picasso; Madoura Studio; 20th-century ceramic art. 
